\title{
Parental Attachment, Coping Efficacy and Antisocial Behavior among Adolescents from Divorced Family in Selangor, Malaysia
}

\author{
Siti Nor Yaacob (Corresponding author) \\ Family, Adolescent and Child Research Center of Excellence (FACE) \\ Faculty of Human Ecology, Universiti Putra Malaysia \\ 43400 Serdang, Selangor, Malaysia \\ Tel: 60-3-894-67088Ｅ-mail: sitinor@upm.edu.my
}

Farah Azimah Idris

Idrissi International School

Setia Alam 40170 Shah Alam, Selangor, Malaysia

Tel: 60-17-204-8116 E-mail: farahazimah@yahoo.com

Gan Su Wan

Faculty of Human Ecology, Universiti Putra Malaysia

43400 Serdang, Selangor, Malaysia

Tel: 60-17-778-6383 E-mail: gansuwan@gmail.com

Received: July 10, 2014 Accepted: August 2, 2014 Published: January 1, 2015

doi:10.5296/jmr.v7i2.6954 URL: http://dx.doi.org/10.5296/jmr.v7i2.6954

\begin{abstract}
The main purpose of this study was to determine the relationships between parental attachment, coping efficacy and antisocial behavior among adolescents from divorced families. Respondents were 170 secondary school students aged 13 to 17, selected using purposive sampling technique. Self-administered questionnaire was used in data collection. Adolescents' attachment with parent was assessed with Parent Attachment subscale from
\end{abstract}




\section{Macrothink}

Journal of Management Research

ISSN 1941-899X 2015, Vol. 7, No. 2

Inventory of Parent and Peer Attachment (IPPA). Coping Self-Efficacy Scale (CSES) and Subtypes of Antisocial Behavior Questionnaire (STAB) were used to measure adolescents' coping efficacy and antisocial behavior respectively. Correlation analysis showed that mother attachment $(\mathrm{r}=-.219, \mathrm{p}<.01)$ and coping efficacy $(\mathrm{r}=-.365, \mathrm{p}<.001)$ had significant negative correlation with antisocial behavior. Coping efficacy fully mediated the relationship between mother attachment and antisocial behavior $(Z=-3.197, p<.001)$. Intervention or prevention programs should target both mothers and children from divorced families.

Keywords: Antisocial behavior, Coping efficacy, Divorce, Parental attachment, Adolescents 


\section{Introduction}

Statistics indicated that divorce cases are gradually increasing in Malaysia. There were a total of 38,273 divorce cases reported in the year 2012; an increase by 3,159 cases from the year 2011 (Department of Statistics Malaysia, 2013). Amongst all states, Selangor reported the highest number of divorce cases. Divorce defined as the legal separation of couples (Malaysia Law, 2006) or marital dissolution legally and socially (Price-Bonham \& Balswick, 1980), is an event that elicits many changes to children, parents and even family system (Brooks, 2011; Cheung, 2012). Divorce cause family disruptions that bring direct disturbances on adolescent development. Qualitative study conducted in Malaysia revealed that adolescents from divorced families tend to experience negative emotions, internalizing and externalising behaviour (Daisy \& Nik Ahmad, 2013). This study reported that adolescents from divorced families tend to feel sad, angry and frustrated; while some of them will become rebellious and less active in social life. Adolescents from divorced families experienced higher levels of externalizing and internalizing behavior, lower academic achievement and social relationships (Lansford, 2009); anxiety and depression (Strohschein, 2005); insecure and lower level of parental attachment (Brennan \& Shaver, 1998); and higher involvement in delinquency and antisocial behavior (Burt, Barnes, McGue, \& Iacono, 2008; Demuth \& Brown, 2004; Rodgers \& Rose, 2002; Rozumah, Krauss, Siti Nor, \& Tan, 2011). As compared with intact families, children from divorced families tend to get lower scores on behavioural and psychological adjustment, self-concept and social competence (Amato, 2001; Amato \& Keith, 1991).

Antisocial behavior refers to actions that harm others, violate societal norms, and/or violate the personal or property rights of others (Burt, 2009). Farrington (2005) defined antisocial behavior as a set of behaviors which is against any established rules or normal behaviors; during childhood and adolescence, antisocial behavior included impulsiveness, behavioral disorders, stealing, vandalism, physical and psychological aggression, bullying, and running away from home. Statistics reported that number of juvenile offenders increase from 4,801 in the year 2011 to 5,316 in the year 2012 (Department of Statistics, Malaysia, 2012; 2013a). Prior study showed that adolescents from divorced family tend to be more involved in antisocial behavior than adolescents from traditional family (Neher \& Short, 1998). Adolescents from divorced family might have lower level of parental supervision, involvement and parent-child closeness. In addition, adolescents' ability such as coping skills may also influence their engagement in antisocial behavior (Hampel \& Petermann, 2006).

Parental attachment refers to parent-child relationships which provide a secure base for adolescents to independently discover and master new environments (Armsden et al., 1987). It is believed that adolescents who have secure attachment with parents are less likely to engage in antisocial behavior. Insecure attachment was associated with parental negativity and rejection (Ainsworth, Blehan, Waters, \& Wall, 1978). Divorce affected the trust between parents and adolescents (Glatz, 2006) and lead to insecure parent-child relationships (Fraley \& Heffernan, 2013). Poor mother-adolescent relationship contributes to higher delinquency problem among adolescents from divorced family (Nooshin, Siti Nor, \& Rumaya, 2013). Quality of parent-adolescent relationship was found to be positively related to adolescents' 
self-esteem (Nakisa, Siti Nor, Ma'rof, Parisa, \& Nooshin, 2014; Nooshin \& Siti Nor, 2012), which in turn might contribute to aggressive behavior (Simon, Paternite, \& Shore, 2001). Adolescents who lack of secure attachment with their parents tend to be more anxious and depressed, have lower self-regulation and exhibit social withdrawal (Lee, Abdullah, Elias, \& Uli, 2010).

Coping efficacy is a universal belief that individual can deal both with demands made and the emotions aroused by a situation (Sandler, Tein, Mehta, Wolchick, \& Ayers, 2000). Adolescents use active coping strategies in response to stressful situations related to school and peers, but they rarely use coping skill when dealing with stressful events related to self and parents (Seiffge-Krenke, Aunola, \& Nurmi, 2009). During the process of overcoming stressors from parental divorce, coping skills is important for adolescents. Adolescents with coping and adjustment ability are less likely to be affected by the changes of family structure and life transition. Past study found that adolescents from divorced family had lower coping skills than those from non-divorced family (Neher \& Short, 1998). Adolescents from divorced families with poor coping skills are more vulnerable to negative life events.

Adolescents who reported positive attachment with parents were less delinquent (Lim, Muslihah, Sa'odah, \& Wu, 2013) and used more active coping strategies (Locke \& Zimmer-Gembeck, 2007). Longitudinal study found that improvement in mother-child relationship contributed to the development of coping efficacy and active coping among children (Velez, Wolchik, Tein, \& Sandler, 2011). Coping ability assists adolescents to deal with emotional and behavioral problems positively (Hampel \& Petermann, 2006). Adolescents with higher ability to manage and control emotions were less likely to engage in aggressive behaviors (Downey, Johnston, Hansen, Birney, \& Stough, 2010). Secure attachment could predict higher constructive coping skills and reduce antisocial behavior among adolescents (Howard \& Medway, 2004).

Based on the brief overview above, this study aimed to examine the relationships between parent-adolescent attachment, coping efficacy and antisocial behavior among adolescents from divorced family. In addition, the study also examined the role of coping efficacy in the relationship between parent-adolescent attachment and antisocial behavior.

\section{Methodology}

\subsection{Participants and Location}

The present study involved 170 school-going adolescents aged 13 to 17 years from divorced family identified from selected secondary schools in Selangor. Purposive sampling was used whereby sample selection was promoted by the school's counselor according to the criteria that have been chosen. Criteria for respondents are adolescents come from divorced family and currently living with their mother only (not staying with fathers). A self-administered questionnaire was used to collect data. Confidentiality and anonymity of respondents were guaranteed. The respondents were briefed on the objectives of this research. The respondents consisted of $74(43.5 \%)$ males and $96(56.5 \%)$ females. Majority of the respondents are Malays $(n=150,88.2 \%)$, followed by Indian $(n=12,7.1 \%)$ and Chinese $(n=8,4.7 \%)$. 


\subsection{Measures}

Parent-Adolescent Attachment. Adolescent attachment with parent was assessed with Parent Attachment subscale from Inventory of Parent and Peer Attachment (IPPA) by Armsden and Greenberg (1987). This subscale was used to measure adolescents' perceptions of the positive and negative affective/cognitive dimension of relationship with their mother. The subscale has 25 -items. Adolescents rate each item with a 5 -point Likert scale $(1=$ never true, $2=$ not very often true, $3=$ sometimes true, $4=$ often true and $5=$ always true). The score ranges from 25 to 125 . Higher score indicates higher level of attachment with mothers. Cronbach alpha of mother-adolescent attachment in the current study is .888.

Coping Efficacy. Coping efficacy of adolescents was measured by Coping Self-Efficacy Scale (CSES) which was developed by Chesney (2006). The scale has 26-items that assess adolescents' confidence in performing coping behaviors when faced with life challenges. Adolescents response the items with an 11-point scale $(0=$ "cannot do at all" to $10=$ "certain can do"). The score ranges from 0 to 260. Higher score indicates higher level of coping self-efficacy. The coefficient alpha of CSES in the current study is .836 .

Antisocial Behavior. This study assessed antisocial behavior of the adolescents using the Subtypes of Antisocial Behavior Questionnaire (STAB) by Burt (2009). This 32-items questionnaire measured rule-breaking, physically aggressive, and socially aggressive antisocial behaviors. However, with author's permission, one item was omitted as it is considered inappropriate for the targeted respondents. Therefore, this study utilized 31-items. Adolescents rate the item with a 5-point Likert scale ( $1=$ never, $2=$ hardly ever, $3=$ =sometimes, $4=$ frequently and $5=$ nearly all the time). The score ranges from 31 to 155 . Higher total score indicates higher level of antisocial behavior among the respondents. The Cronbach alpha for STAB in this study is .911.

\section{Results and Findings}

\subsection{Correlation between Variables}

Data were analyzed by using Statistical Package for Social Science (SPSS-version 20). Descriptive, correlation and regression analysis were conducted to examine the study objectives. Table 1 showed the means, standard deviations and inter-correlations for the main variables. All of the variables were correlated with each other. Parent-adolescent attachment $(\mathrm{r}=-.219, \mathrm{p}<.01)$ and coping efficacy $(\mathrm{r}=-.365, \mathrm{p}<.001)$ had significant negative correlations with antisocial behavior. Adolescents who perceived higher levels of parental attachment and reported higher coping efficacy tend to have lower involvement in antisocial behavior. 
Table 1. Means, Standard Deviations (SD), and Zero-Order Correlations for Variables $(\mathrm{N}=170)$

\begin{tabular}{|l|l|l|l|l|c|}
\hline \multicolumn{1}{|c|}{ Variables } & \multicolumn{1}{c|}{ Mean } & SD & 1 & \multicolumn{1}{c|}{2} & 3 \\
\hline $\begin{array}{l}\text { 1. Parent-adolescent } \\
\text { Attachment }\end{array}$ & 90.46 & 15.695 & - & $.352^{* * *}$ & $-.219^{* *}$ \\
\hline 2. Coping Efficacy & 150.52 & 29.907 & - & - & $-.365^{* * *}$ \\
\hline 3. Antisocial Behavior & 54.18 & 15.835 & - & - & - \\
\hline
\end{tabular}

Note: $* * \mathrm{p}<.01 ; * * * \mathrm{p}<.001$.

\subsection{Mediation Analysis}

In order to test the mediating role of coping efficacy in the relationship between parent-adolescent attachment and antisocial behavior, linear regression analysis was conducted to examine regression coefficient for each path. Steps of linear regression analysis were conducted as shown in Table 2. The results presented in Table 2 showed that parent-adolescent attachment $(\mathrm{B}=-.221, \mathrm{p}<.01)$ and coping efficacy $(\mathrm{B}=-.193, \mathrm{p}<.001)$ contributed significantly to antisocial behavior. Higher levels of parent-adolescent attachment and coping efficacy contributed to lower level of antisocial behavior among respondents. Parent-adolescent attachment $(\mathrm{B}=.671, \mathrm{p}<.001)$ also significantly predicted coping efficacy. Higher level of attachment to mothers enhanced coping efficacy of adolescent children. In Step 4, parent-adolescent attachment and coping efficacy were entered together as the predictors of antisocial behavior. The regression coefficient of parent-adolescent attachment to antisocial behavior decreased and becomes non-significant $(\mathrm{B}=-.104, \mathrm{p}>.05)$. Thus, coping efficacy fully mediated the relationship between parent-adolescent attachment and antisocial behavior. This mediation effect was further tested with Sobel test (Baron \& Kenny, 1986). The results of Sobel test $(Z=-3.197, p<.001)$ confirmed that coping efficacy mediated the relationship between parent-adolescent attachment and antisocial behavior. Results revealed that parent-adolescent attachment indirectly influence antisocial behavior through coping efficacy. Figure 1 showed the full mediational model.

Table 2. Relationship between Parent-adolescent Attachment and Antisocial Behavior mediated by Coping Efficacy $(\mathrm{N}=170)$

\begin{tabular}{|l|l|l|l|l|l|l|}
\hline Step & \multicolumn{1}{|c|}{ IV } & \multicolumn{1}{c|}{ DV } & \multicolumn{1}{c|}{ B } & \multicolumn{1}{c|}{ SE } & \multicolumn{1}{c|}{ Beta } & \multicolumn{1}{c|}{ t } \\
\hline 1 & $\begin{array}{l}\text { Parent-Adolescent } \\
\text { Attachment }\end{array}$ & $\begin{array}{l}\text { Antisocial } \\
\text { Behavior }\end{array}$ & $-.221^{* *}$ & .076 & -.219 & -2.912 \\
\hline 2 & $\begin{array}{l}\text { Parent-Adolescent } \\
\text { Attachment }\end{array}$ & Coping Efficacy & $.671 * * *$ & .138 & .352 & 4.876 \\
\hline 3 & Coping Efficacy & $\begin{array}{l}\text { Antisocial } \\
\text { Behavior }\end{array}$ & $-.193 * * *$ & .038 & -.365 & -5.083 \\
\hline 4 & $\begin{array}{l}\text { Parent-Adolescent } \\
\text { Attachment }\end{array}$ & $\begin{array}{l}\text { Antisocial } \\
\text { Behavior }\end{array}$ & -.104 & .077 & -.104 & -1.352 \\
\hline & Coping Efficacy & & $-.174 * * *$ & .041 & -.329 & -4.293 \\
\hline
\end{tabular}

Note: $\mathrm{B}=$ Unstandardized coefficient; $\mathrm{SE}=$ Standard Error; Beta $=$ Standardized coefficient; ${ }^{*} \mathrm{p}<.05$; 
${ }^{* *} \mathrm{p}<.01 ; * * \mathrm{p}<.001 ;$ Sobel test: $\mathrm{Z}=-3.197, \mathrm{p}<.001$.

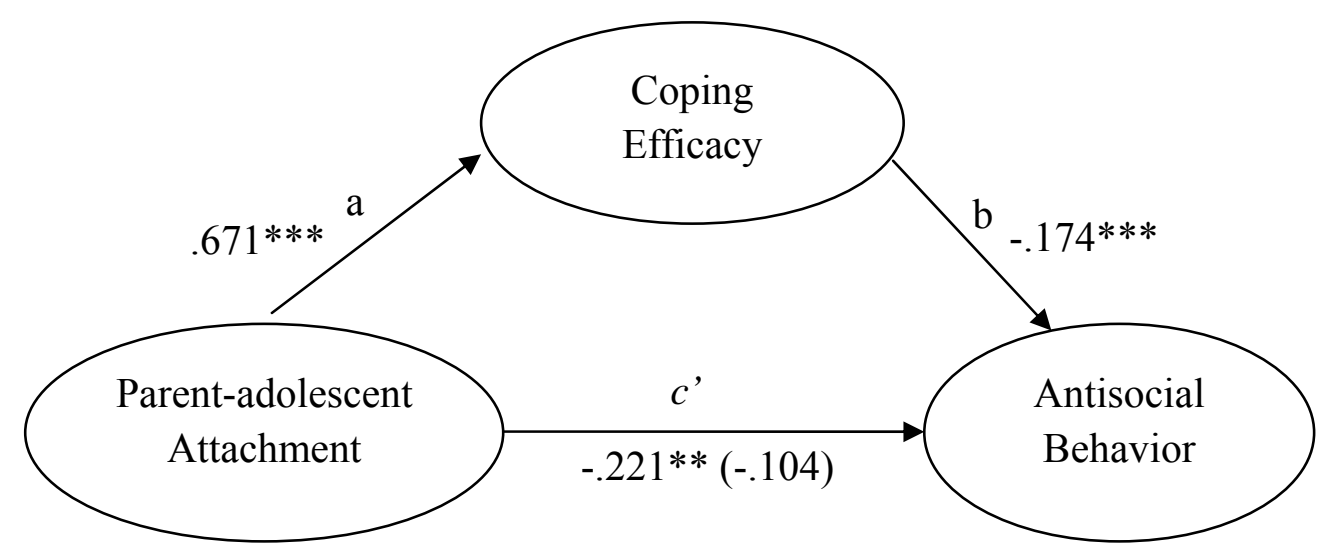

Figure 1. Mediation Model.

Note: ${ }^{*} \mathrm{p}<.05 ; * * \mathrm{p}<.01 ; * * * \mathrm{p}<.001$; Path coefficients are presented in unstandardized units. Path coefficient in parenthesis represented magnitude of direct effect after controlled coping efficacy.

\section{Conclusions, Implications and Significance}

Findings indicated that when adolescents are highly attached with their parents, they have lower tendency to involve themselves in antisocial behavior. The finding is consistent with past studies which found that adolescents are less likely to engage in delinquent and aggressive behavior when they are attached to their parents (Lim et al., 2013; Gallarin \& Alfonso, 2012; Nooshin et al., 2013). The findings on coping efficacy and antisocial behavior supported past evidence which noted that adolescents who are able to cope with negative emotions are less likely to engage in aggressive behaviors (Downey et al., 2010).

Coping efficacy fully mediated the relationship between parent-adolescent attachment and antisocial behavior. The results of full mediation showed that mother-adolescent attachment influence adolescents' antisocial behaviour predominantly through adolescents' ability to cope with stressful events. Mothers should play appropriate parenting practices to nurture coping efficacy among adolescents; and consequently prevent adolescents from engaging in antisocial behavior. Previous study found that parent-attachment security in adolescence could predict more constructive coping skills and reduce the antisocial behavior among adolescents (Howard \& Medway, 2004).

Results of the current study highlight the importance of mother-adolescent attachment and coping efficacy in preventing antisocial behaviour among adolescents. Intervention or prevention programs should target both mothers and children from divorced families. Mothers must be empowered with appropriate parenting skill in order to establish close and meaningful relationship with their adolescent child, and consequently nurture their adolescent 
child's coping efficacy. Adolescent children who do not feel deprived and able to cope with challenges tend to avoid various forms of antisocial behaviour. Meanwhile, programs targeted for adolescents from divorced family must emphasize the development of coping efficacy among adolescents; so that they can cope with challenges of family disruption and thus prevent them from involving in various forms of antisocial behavior. Thus, various parties such as school authority can plan and implement programs that help these adolescents to develop coping skills. Students with high coping efficacy may indirectly reduce antisocial and discipline problems in school. Government can also organize more activities and programs to empower parents and caregivers with the ability to establish positive and secure attachment with their adolescent child, as positive attachment impedes adolescents of divorced family from antisocial behaviour tendencies.

\section{References}

Ainsworth, M. D. S., Blehan, M. C., Waters, E., \& Wall, S. (1978). Patterns of attachment: A psychological study of the strange situation. Hillsdale, N. J.: Erlbaum.

Amato, P. R. (2001). Children of divorce in the 1990s: An update of the Amato and Keith (1991) meta-analysis. Journal of Family Psychology, 15, 355-70. http://dx.doi.org/10.1037/0893-3200.15.3.355

Amato, P. R., \& Keith, B. (1991). Parental divorce and the wellbeing of children: A meta-analysis. Psychological Bulletin, $110, \quad 26-46$. http://dx.doi.org/10.1037/0033-2909.110.1.26

Armsden, G. C., \& Greenberg, M. T. (1987). The inventory of parent and peer attachment: Relationships to well-being in adolescence. Journal of Youth and Adolescence, 16(5), 427-454. http://dx.doi.org/10.1007/BF02202939

Baron, R. M., \& Kenny, D. A. (1986). The moderator-mediator variable distinction in social psychological research: Conceptual, strategic and statistical considerations. Journal of $\begin{array}{llll}\text { Personality and Social } & \text { Psychology, } & \text { 51(6), }\end{array}$ http://dx.doi.org/10.1037/0022-3514.51.6.1173

Brennan, K. A., \& Shaver, P. R. (1998). Attachment styles and personality disorders: Their connections to each other and to parental divorce, parental death, and perceptions of parental $\begin{array}{llll}\text { caregiving. Journal of } & \text { 835-878. }\end{array}$ http://dx.doi.org/10.1111/1467-6494.00034

Brooks, J. (2011). The process of parenting (8th ed.). United States: McGraw-Hill.

Burt, S. A., \& Donnellan, M. B. (2009). Development and validation of the subtypes of antisocial behavior questionnaire. Aggressive Behavior, 35, 376-398. http://dx.doi.org/10.1002/ab.20314

Burt, S. A., Barnes, A. R., McGue, M., \& Iacono, W. G. (2008). Parental divorce and adolescent delinquency. Development Psychology, 44(6), 1668-1677. http://dx.doi.org/10.1037/a0013477

Chesney, M. A., Neilands, T. B., Chambers, D. B., Taylor, J. M., \& Folkman, S. (2006). A 
validity and reliability of the coping self-efficacy scale. British Journal of Health Psychology, 11, 421-437. http://dx.doi.org/10.1348/135910705X53155

Cheung, S-K. (2012). Stressors and well-being of divorced women in Hong Kong. Asia Pacific Journal of Social Work and Development, 9(1), $42-57$.

Daisy, J. C. O., \& Nik Ahmad, H. I. (2013). The effect of parental divorce on the psychological wellbeing of Muslim youth: Implications for counselling and psychotherapy. Journal of Educational Studies, 1(1), 55-97.

Demuth, S., \& Brown, S. L. (2004). Family structure, family processes, and adolescent delinquency: The significance of parental absence versus parental gender. Journal of Research in Crime and Delinquency, 41(1), 58-81. http://dx.doi.org/10.1177/0022427803256236

Department of Statistics, Malaysia. (2012). Social statistics bulletin. Retrieved from http://statistics.gov.my/portal/download_Labour/files/BPS/Buletin_Perangkaan_Sosial_2012. pdf

Department of Statistics, Malaysia. (2013). State/district social statistics. Retrieved from http://statistics.gov.my/portal/download_Labour/files/PSND/Perangkaan_Sosial_Negeri-Daer ah_Malaysia2013.pdf

Department of Statistics, Malaysia. (2013a). Social statistics bulletin. Retrieved from http://statistics.gov.my/portal/download_Labour/files/BPS/Buletin_Perangkaan_Sosial_2013. pdf

Downey, L. A., Johnston, P. J., Hansen, K., Birney, J., \& Stough, C. (2010). Investigating the mediating effects of emotional intelligence and coping on problem behaviors in adolescents, $\begin{array}{llll}\text { Australian. Journal of 20-29. } & \text { Psychology, }\end{array}$ http://dx.doi.org/10.1080/00049530903312873

Farrington, D. P. (2005). Childhood origins of antisocial behavior. Clinical Psychology and Psychotherapy, 12, 177-190. http://dx.doi.org/10.1002/cpp.448

Fraley, R. C., \& Hefferman, M. E. (2013). Attachment and parental divorce: A test of the diffusion and sensitive period hyphoteses. Personality and Social Psychology Bulletin, 39(2), 1199-1213. http://dx.doi.org/10.1177/0146167213491503

Gallarin, M., \& Alonso-Arbiol, I. (2012). Parenting practices, parental attachment and aggressiveness in adolescence: A predictive model. Journal of Adolescence, 35, 1601-1610. http://dx.doi.org/10.1016/j.adolescence.2012.07.002

Glatz, T. (2006). Parent-adolescent relationships after a divorce. Retrieved from http://www.diva-portal.org/smash/record.jsf?pid=diva2:136991

Hampel, P., \& Petermann, F. (2006). Perceived stress, coping and adjustment in adolescents. Journal of Adolescent Health, 38, 409-415. http://dx.doi.org/10.1016/j.jadohealth.2005.02.014

Howard, M. S., \& Medway, F. J. (2004). Adolescents' attachment and coping with stress. 
Psychology Schools. 41, 391-402. http://dx.doi.org/10.1002/pits.10167

Lansford, J. E. (2009). Parental divorce and children's adjustment. Perspectives on Psychological Science, 4(2), 140-152. http://dx.doi.org/10.1111/j.1745-6924.2009.01114.x

Lee, P. G., Abdullah, M. C., Elias, H., \& Uli, J. (2010). Development of antisocial behavior. Procedia Social and Behavioral Sciences, 7(C), 383-388.

Lim, J. C., Muslihah, H., Sa'odah, A., \& Wu, S. L. (2013). Parental attachment, peer attachment, and delinquency among adolescents in Selangor, Malaysia. Asian Social Science, 9(15), 214-219. http://dx.doi.org/10.5539/ass.v9n15p214

Locke, E. M., \& Zimmer-Gembeck, M. J. (2007). The socialization of adolescent coping behaviors: Relationships with families and teachers. Journal of Adolescence, 30, 1-16. http://dx.doi.org/10.1016/j.adolescence.2005.03.001

Malaysia Law. (2006). Law reform (Marriage and Divorce) Act 1976. Retrieved from http://www.commonlii.org/my/legis/consol_act/lrada1976272/

Nakisa, P., Siti Nor, Y., Ma'rof, R., Parisa, P., \& Nooshin, S. E. (2014). Parental attachment, inter-parental conflict and late adolescent's self-efficacy. Asian Social Science, 10(8), 123-131.

Neher, L. S., \& Short, J. L. (1998). Risk and protective factors for children's substance use and antisocial behavior following parental divorce. American Journal of Orthopsychiatry, 68, 154-161. http://dx.doi.org/10.1037/h0080281

Nooshin, S. E., \& Siti Nor, Y. (2012). Correlates of self-esteem among adolescents of divorced families. Archives Des Science, 65(8), 52-59.

Nooshin, S. E., Siti Nor, Y., \& Rumaya, J. (2013). Predictors of delinquency among adolescents of divorced families. Asian Social Science, 9(11), 41-49.

Price-Bonham, S., \& Balswick, J. O. (1980). The Noninstitutions: Divorce, desertion, and remarriage. Journal of Marriage and Family, 42(4), 959-972. http://dx.doi.org/10.2307/351835

Rodgers, K. B., \& Rose, H. A. (2002). Risk and resiliency factors among adolescents who experience marital transitions. Journal of Marriage and the Family, 64(4), 1024-1037. http://dx.doi.org/10.1111/j.1741-3737.2002.01024.x

Rozumah, B., Krauss, S. E., Siti Nor, Y., \& Tan, J-P. (2011). Family processes as predictors of antisocial behaviors among adolescents from urban, single-mother Malay families in Malaysia. Journal of Comparative Family Studies, 42(4), 509-522.

Sandler, I. N., Tein, J. Y., Mehta, P., Wolchick, S., \& Ayers, T. (2000). Coping efficacy and psychological problems of children of divorce. Child Development, 71(4), 1099-1118. http://dx.doi.org/10.1111/1467-8624.00212

Seiffge-Krenke, I., Aunola, K., \& Nurmi, J. (2009). Changes in stress perception and coping during adolescence: The role of situational and personal factors. Child Development, 80(1), 259-279. http://dx.doi.org/10.1111/j.1467-8624.2008.01258.x 


\section{Macrothink

Simon, K. J., Paternite, C. E., \& Shore, C. (2001). Quality of parent/adolescent attachment and aggression in young adolescents. Journal of Early Adolescence, 21, 182-203. http://dx.doi.org/10.1177/0272431601021002003

Strohschein, L. (2005). Parental divorce and child mental health trajectories. Journal of Marriage and Family, 67, 1286-1300. http://dx.doi.org/10.1111/j.1741-3737.2005.00217.x

Velez, C. E., Wolchik, S. A., Tein, J-Y., \& Sandler, I. (2011). Protecting children from the consequences of divorce: A longitudinal study of the effects of parenting on children's coping $\begin{array}{llll}\text { processes. } & \text { Child } & \text { 244-257. }\end{array}$ http://dx.doi.org/10.1111/j.1467-8624.2010.01553.x

\section{Copyright Disclaimer}

Copyright for this article is retained by the author(s), with first publication rights granted to the journal.

This is an open-access article distributed under the terms and conditions of the Creative Commons Attribution license (http://creativecommons.org/licenses/by/3.0/). 